\title{
Pengendalian Bahaya Fisik pada Pekerjaan Dokter Gigi
}

\author{
Juliatri
}

Pascasarjana Program Studi Ilmu Kesehatan Masyarakat, Minat Keselamatan dan Kesehatan Kerja Universitas Sam Ratulangi Manado

Program Studi Pendidikan Dokter Gigi Fakultas Kedokteran Universitas Sam Ratulangi Manado

Email: juliatri31@unsrat.ac.id

\begin{abstract}
Dentists are at risk of experiencing a number of occupational hazards including physical hazards. Potential physical hazards include noise, lighting, ionizing and non-ionizing radiation, percutaneous exposure incident (PEI), and extreme temperatures. Efforts to control physical hazards based on the hierarchy of hazard control in the work of dentists are substitution, engineering, administration, and the use of personal protective equipment (PPE).
\end{abstract}

Keywords: physical hazards, hazard control hierarchy

\begin{abstract}
Abstrak: Dokter gigi merupakan salah satu profesi yang berisiko mengalami sejumlah bahaya akibat pekerjaan, termasuk bahaya fisik. Potensi bahaya fisik antara lain kebisingan, pencahayaan, radiasi ionisasi dan nonionisasi, percutaneous exposure incident (PEI), dan suhu ekstrim. Upaya pengendalian bahaya fisik berdasarkan hierarki pengendalian bahaya pada pekerjaan dokter gigi yaitu substitusi, rekayasa engineering, administrasi, dan penggunaan alat pelindung diri (APD).
\end{abstract}

Kata kunci: bahaya fisik, hierarki pengendalian bahaya

\section{Pendahuluan}

Setiap pekerjaan memiliki potensi bahaya yang timbul pada saat seseorang melakukan pekerjaan tersebut. Pekerja mempunyai risiko terhadap masalah kesehatan yang disebabkan oleh proses kerja, lingkungan kerja serta perilaku kesehatan pekerja. Selain penyakit akibat kerja dan kecelakaan kerja, pekerja juga berisiko menderita penyakit menular dan tidak menular. $^{1}$

Dokter gigi merupakan salah satu profesi yang berisiko mengalami sejumlah bahaya akibat pekerjaan. Bahaya tersebut antara lain pajanan terhadap agen penyebab infeksi (termasuk human immunodeficiency virus dan virus hepatitis), radiasi, kebisingan, gangguan muskulo-skeletal, masalah psikologis, dermatitis, gangguan pernapasan, dan percikan bahan gigi pada mata. ${ }^{2}$

Penelitian yang dilakukan oleh Baig tahun 2016 terhadap 130 dokter gigi yang terlibat dalam praktik klinis menunjukkan $122(93,8 \%)$ memiliki risiko kerja selama praktik. Cervical back pain diamati pada $81,96 \%$ dokter gigi diikuti oleh nyeri sendi lutut/siku 53,27\%, infeksi mata 44,615\%, gangguan pendengaran $40,98 \%$, stres psikologis $41,80 \%$, dan alergi bahan $12,29 \%$. $^{3}$ Masalah kesehatan akibat pekerjaan juga ditemukan pada dokter gigi di Kroasia yaitu lebih dari $78,18 \%$ dokter gigi yang disurvei mengalami nyeri punggung bagian atas, 76,97\% menderita nyeri punggung bawah, 29,29\% mengalami masalah kulit, $46,87 \%$ gangguan penglihatan, $19,03 \%$ masalah pendengaran, dan $15,76 \%$ dokter gigi mengalami gangguan neurologik. ${ }^{4}$ Penelitian yang dilakukan oleh Al Rawi et $\mathrm{al}^{5}$ tahun 2019 juga menunjukkan 20 praktisi gigi (22,2\% dari sampel penelitian) menderita gangguan pendengaran. Telinga kiri 
lebih terpengaruh daripada telinga kanan, tetapi tidak bermakna secara statistik. Pada penelitian tersebut juga dijelaskan adanya hubungan langsung antara jam kerja per minggu dan kapasitas pendengaran, tetapi tidak bermakna secara statistik. Kapasitas pendengaran terendah terlihat pada lakilaki dibandingkan perempuan. ${ }^{5}$

\section{Hierarki Pengendalian Bahaya}

Hierarki pengendalian bahaya atau risiko merupakan hal dasar yang harus dipahami oleh seluruh praktisi keselamatan dan kesehatan kerja karena akan menjadi dasar dalam pengambilan keputusan terkait dengan pengendalian risiko (Gambar 1). ${ }^{6}$ Hierarki pengendalian bahaya bertujuan untuk menyediakan pendekatan sistematik guna peningkatan keselamatan dan kesehatan, mengeliminasi bahaya dan mengurangi atau mengendalikan risiko keselamaan dan kesehatan kerja. Dalam hierarki pengendalian bahaya, pengendalian yang lebih atas lebih efektif daripada pengendalian yang lebih bawah. ${ }^{7}$

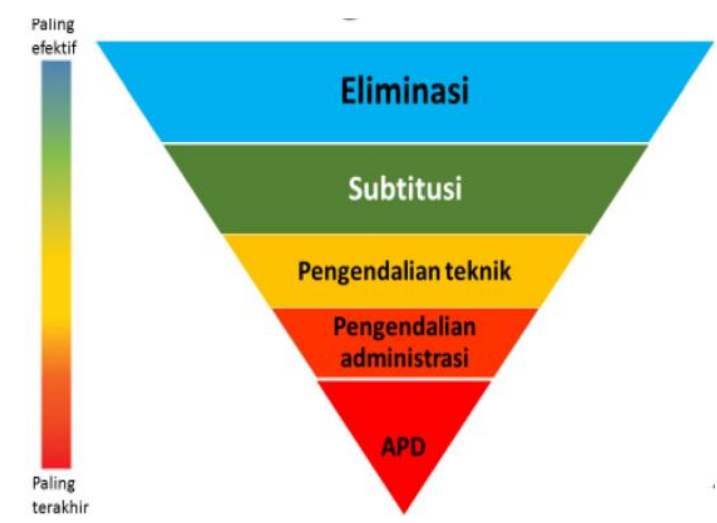

Gambar 1. Hierarki pengendalian bahaya. Sumber: NIOSH, $2015 .^{6}$

Hierarki pengendalian bahaya dalam sistem manajemen keselamatan dan kesehatan kerja yaitu eliminasi, substitusi, rekayasa engineering/pengendalian teknik, administrasi, dan penggunaan alat pelindung diri (APD). Eliminasi merupakan langkah pengendalian yang menjadi pilihan pertama dan paling efektif untuk mengendalikan pajanan karena menghilangkan bahaya dari tempat kerja. Namun, beberapa bahaya sulit untuk benar-benar dihilangkan dari tempat kerja. ${ }^{6,8}$ Contoh tindakan eliminasi ialah berhenti menggunakan zat kimia beracun dan mengeliminasi pekerjaan yang monoton sehingga dapat menghilangkan stres negatif. ${ }^{7}$ Substitusi merupakan upaya penggantian bahan, alat atau cara kerja dengan alternatif lain dengan tingkat bahaya yang lebih rendah sehingga dapat menekan kemungkinan terjadinya dampak yang serius. ${ }^{6,9}$ Eliminasi dan substitusi merupakan pengendalian yang paling efektif dalam mengurangi bahaya, juga cenderung paling sulit untuk diterapkan dalam proses yang ada. Jika prosesnya masih dalam tahap desain atau pengembangan, eliminasi dan substitusi bahaya mungkin tidak mahal dan mudah diimplementasikan. Untuk proses yang telah berjalan, perubahan besar dalam peralatan dan prosedur mungkin diperlukan untuk menghilangkan atau mengganti bahaya. ${ }^{9}$ Contoh substitusi ialah mengganti tensi air raksa dengan tensi digital, dan mengganti kompresor tingkat kebisingan tinggi dengan tipe kompresor dengan kebisingan rendah. ${ }^{6}$

Tahapan rekayasa teknik merupakan pengendalian rekayasa desain alat dan/atau tempat kerja. ${ }^{7}$ Rekayasa engineering lebih efektif untuk mengendalikan paparan pekerja di tempat kerja daripada menggunakan alat pelindung diri (APD). Rekayasa engineering yang dirancang dengan baik bisa sangat efektif dalam melindungi pekerja. Biaya awal rekayasa engineering dapat lebih tinggi daripada biaya kontrol administratif atau APD, tetapi dalam jangka panjang, biaya operasi seringkali lebih rendah, dan dalam beberapa kasus dapat memberikan penghematan biaya di area lain dari proses. ${ }^{9}$ Contoh pengendalian dalam rekayasa engineering ialah pemakaian pelindung mesin pada alat dengan tingkat kebisingan tinggi, ${ }^{6,7}$ pengaturan sistem ventilasi, dan penyekatan ruangan. ${ }^{7}$

Pengendalian administrasi merupakan pengendalian dari sisi pekerja yang akan melakukan pekerjaan. Dengan adanya metode kerja diharapkan pekerja akan mematuhi, serta memiliki kemampuan dan keahlian cukup untuk menyelesaikan pekerjaan secara aman. Jenis pengendalian ini antara 
lain adanya standar operasional prosedur (SOP), pelatihan, pengawasan, modifikasi perilaku, jadwal kerja, dan jadwal istirahat. $^{8}$

Alat pelindung diri (APD) atau yang dikenal sebagai personal protective equipment (PPE) adalah peralatan keselamatan untuk melindungi diri terhadap potensi bahaya kecelakaan kerja. Alat pelindung diri merupakan kelengkapan yang wajib digunakan saat bekerja untuk menjaga keselamatan pekerja itu sendiri dan orang di sekelilingnya, serta menjadi upaya terakhir dalam meminimalkan bahaya. ${ }^{10}$ Alat pelindung diri ini dibagi atas: 1) pelindung mata dan wajah, 2) pelindung pernapasan, 3) pelindung kepala, 4) pelindung kaki, 5) pelindung tangan, 6) pelindung pendengaran, 7) pelindung tubuh, dan 8) sabuk pengaman. ${ }^{10}$

\section{Klasifikasi Potensi Bahaya}

Penyakit akibat kerja dapat disebabkan oleh potensi bahaya yang mengancam kesehatan pekerja di tempat kerja. Potensi bahaya tersebut dibagi menjadi lima golongan yaitu: ${ }^{1}$ fisik, kimia, biologi, ergonomik, dan psikososial. Golongan fisik, contohnya suhu ekstrem, bising, pencahayaan, vibrasi, radiasi ionisasi dan nonionisasi, serta tekanan udara. Golongan kimia, yaitu semua bahan kimia dalam bentuk debu, uap, uap logam, gas, larutan, kabut, partikel nano, dan lainnya. Golongan biologi, yaitu bakteri, virus, jamur, bioaerosol, dan lainnya. Golongan ergonomi, contohnya angkat angkut berat, posisi kerja janggal, posisi kerja statis, gerak repetitif, penerangan, visual display terminal (VDT), dan lainnya. Golongan psikososial, seperti beban kerja kualitatif dan kuantitatif, organisasi kerja, kerja monoton, hubungan interpersonal, kerja shift, lokasi kerja, dan lainnya

\section{Pengendalian Bahaya Fisik Berdasarkan Hierarki Pengendalian Bahaya pada Pekerjaan Dokter Gigi}

Pekerjaan dokter gigi memiliki potensi bahaya. Berikut ini ialah potensi bahaya fisik dan upaya pengendalian berdasarkan hierarki pengendalian bahaya.
Kebisingan yang berasal dari kompresor, bor gigi (hand piece high speed), dan genset

Kompresor digunakan sebagai sumber tenaga bor gigi dan alat kedokteran gigi lainnya yang membutuhkan dorongan angin. Kompresor dan hand piece high speed yang beroperasi dari 3900 hingga $12.500 \mathrm{~Hz}$ merupakan faktor utama penyebab kebisingan. Kehilangan pendengaran, tekanan akustik dan gangguan konsentrasi dapat dialami oleh individu yang secara teratur terpapar frekuensi di atas $3000 \mathrm{~Hz}{ }^{2}$ Penelitian yang dilakukan oleh Qsaibati dan Ibrahim $^{11}$ menunjukkan bahwa kebisingan tertinggi pada klinik gigi dihasilkan oleh handpiece micro motor pada saat memotong akrilik (92,2 dB) dan sumber kebisingan terendah $(51,7 \mathrm{~dB})$ yaitu skeler ultrasonik tanpa penggunaan suction. Tingkat kebisingan tertinggi terdapat pada klinik pedodontik $(67,37 \mathrm{~dB}) \cdot{ }^{11}$ Hasil pengukuran tingkat kebisingan di klinik gigi yang dilakukan oleh Elmehdi ${ }^{12}$ menunjukkan bahwa tingkat kebisingan background (ketika tidak ada peralatan gigi yang digunakan) ialah $65 \mathrm{~dB}$, sedangkan tingkat kebisingan ketika terdapat perangkat yang digunakan di klinik gigi bervariasi dari $72 \mathrm{~dB}-85 \mathrm{~dB}$ untuk skeler ultrasonik dan $87 \mathrm{~dB}$ kompresor (Tabel 1).

Tabel 1. Nilai rerata kebisingan di klinik gigi ${ }^{12}$

\begin{tabular}{|c|c|}
\hline Alat & $\begin{array}{c}\text { Rerata tingkat } \\
\text { kebisingan } \\
(\text { dB })^{*}\end{array}$ \\
\hline Background & $65 \pm 2$ \\
\hline Aspirator & $72 \pm 3$ \\
\hline Kompresor udara & $87 \pm 3$ \\
\hline Mixers & $77 \pm 3$ \\
\hline $\begin{array}{l}\text { Handpiece with high } \\
\text { speed air suction }\end{array}$ & $75 \pm 3$ \\
\hline $\begin{array}{l}\text { Handpiece with low } \\
\text { speed air suction }\end{array}$ & $72 \pm 3$ \\
\hline High speed drill & $84 \pm 2$ \\
\hline Skeler ultrasonik & $85 \pm 3$ \\
\hline
\end{tabular}

"diukur menggunakan skala A

Nilai ambang batas (NAB) kebisingan untuk 8 jam kerja per hari ialah sebesar 85 
$\mathrm{dB} .{ }^{13}$ Paparan terhadap kebisingan yang melebihi NAB secara berkelanjutan tanpa menggunakan tindakan pencegahan dan perlindungan merupakan risiko kesehatan serta memiliki efek pendengaran dan nonpendengaran. Efek nonpendengaran meliputi hipertensi, gangguan tidur, penurunan kinerja belajar, stres, gangguan komunikasi dan konsentrasi, serta kelelahan mental. Efek pendengaran terdiri atas gangguan pendengaran permanen dan perubahan pendengaran sementara atau tinitus pada paparan jangka pendek kebisingan. ${ }^{14}$

Berdasarkan hierarki pengendalian bahaya, kebisingan yang berasal dari peralatan kedokteran gigi dapat dilakukan dengan cara, antara lain: substitusi, rekayasa engineering, administrasi, dan menggunakan APD. Substitusi yaitu mengganti kompresor tingkat kebisingan tinggi dengan tipe yang memiliki kebisingan rendah (silent compressor) sehingga dapat meminimalkan risiko gangguan pendengaran., ${ }^{2,6,15}$ Rekayasa engineering dilakukan dengan memindahkan alat yang menjadi sumber bising lebih jauh dari operator, penggunaan peredam suara, membatasi dengan dinding penghalang, menutup sebagian atau keseluruhan sumber kebisingan. ${ }^{15}$ Pelaksanaan administrasi dilakukan dengan memelihara peralatan kedokteran gigi sesuai panduan manual dari pabrik dan tidak menggunakan peralatan yang sudah tua. Dalam beberapa penelitian telah ditunjukkan bahwa peralatan gigi yang rusak atau aus, khususnya hand piece, bor gigi dan skeler, meningkatkan risiko gangguan pendengaran 3-20 kali jika tidak dirawat dengan baik. ${ }^{15}$ Selanjutnya, usia peralatan gigi juga merupakan faktor risiko yang berkontribusi. Messano dan Petti ${ }^{16}$ telah melaporkan bahwa hand piece dengan pemakaian lebih dari 1 tahun dapat memengaruhi efisiensi pendengaran. Menggunakan APD atau perlindungan pribadi dilakukan dengan menggunakan penutup telinga yang mengurangi suara intensitas tinggi hingga 30 hingga $35 \mathrm{~dB} .^{2}$

\section{Penerangan atau pencahayaan yang buruk}

Pencahayaan adalah jumlah penyinaran pada suatu bidang kerja yang diperlukan untuk melaksanakan kegiatan secara efektif. Pencahayaan diukur dalam satuan Luxlumen per meter persegi. Kadar pencahayaan diukur dengan alat pengukur cahaya (Lux meter) yang diletakkan di permukaan tempat kerja atau setinggi perut untuk penerangan umum (kurang lebih 1 meter). ${ }^{1}$

Pencahayaan yang tepat di tempat praktik, baik pencahayaan pada area kerja atau operasi, pencahayaan di tempat penyimpanan bahan dan alat, maupun pencahayaan di ruang tunggu pasien merupakan hal yang sangat penting. ${ }^{17}$ Pencahayaan yang memadai akan meningkatkan presisi kerja, terutama menyangkut prosedur seperti pencocokan warna menggunakan shade guide dan penentuan warna bahan restorasi gigi. ${ }^{17,18}$

Penelitian oleh Alvin ${ }^{18}$ menunjukkan bahwa pencahayaan di 32 tempat praktik dokter gigi pribadi yang diukur tidak ideal untuk melakukan pencocokan warna visual. Penerangan yang buruk merupakan penyebab sakit mata, ketegangan mata, sakit kepala, dan kelelahan mata, sedangkan kecerahan yang berlebihan menyebabkan ketidaknyamanan dan kelelahan visual. $^{2}$ Noel menunjukkan bahwa paparan cahaya dari penggunaan lampu Light-Emitting Diode (LED) pada dental unit dapat menyebabkan kerusakan retina mata. Pada penelitiannya disebutkan paparan selama lima menit tidak menghasilkan pengaruh bermakna, sedangkan paparan sebanyak tiga dan empat kali (durasi setiap paparan selama lima menit) menyebabkan kerusakan pada mata yang bermakna. ${ }^{19}$

Lampu dental unit terdiri atas lampu halogen dan LED. Penggunaan pencahayaan LED intensitas tinggi ini tidak dapat dipungkiri semakin populer di kalangan dokter gigi. Meskipun sebagian besar produsen lampu LED mengiklankan bahwa lampu dental unit yang diproduksi memancarkan cahaya putih terang, tetapi alat ini masih terdiri atas dua spectral band yaitu spectral band biru hingga $445 \mathrm{~nm}$, dan spectral band hijau hingga $555 \mathrm{~nm}$. Green light pada lampu LED tidak menyebabkan kerusakan pada mata, tetapi beberapa pencahayaan LED yang memiliki komponen 
blue light yang kuat dapat menyebabkan bahaya kerusakan retina. ${ }^{19}$

Upaya pengendalian yang dapat dilakukan ialah antara lain rekayasa engineering dan administrasi. Pada rekayasa engineering diupayakan pencahayaan alam maupun buatan agar tidak menimbulkan kesilauan dan memilki intensitas sesuai dengan peruntukannya. ${ }^{1}$ Pencahayaan yang ideal untuk operating light di tempat praktik dokter gigi ialah 20.000 Lux dengan Colour Rendering Index(CRI) lebih dari $90 \%$. Untuk mempertahankan pencahayaan yang optimal, diperlukan pemasangan tirai pada jendela. Standar pencahayaan untuk room light sekitar 200700 Lux dan ruang tunggu pasien 300-400 Lux. ${ }^{17}$ Pengaturan penempatan bola lampu juga dapat dilakukan karena dapat menghasilkan penyinaran yang optimum. ${ }^{1}$ Pemilihan hand piece high speed yang dilengkapi dengan sumber cahaya fiber optic memungkinkan visualisasi yang jauh lebih baik. Hal ini sangat penting karena pencahayaan dari lampu dental unit seringkali sulit diposisikan untuk memberi pencahayaan keseluruhan mulut pasien (Gambar 2). ${ }^{20}$

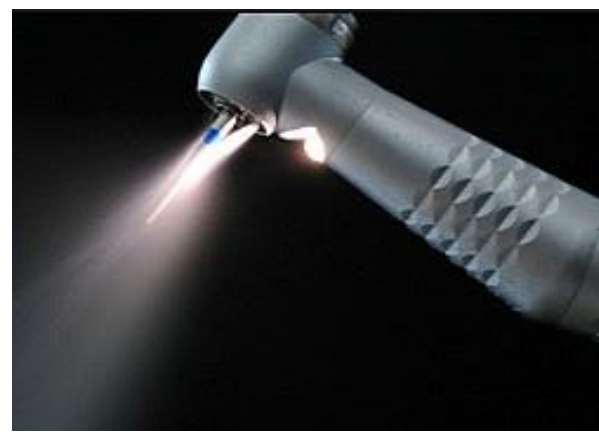

Gambar 2. Hand piece high speed yang dilengkapi dengan sumber cahaya fiber optic. Sumber: Surgiden, $2020 .^{20}$

Pekerjaan dokter gigi tidak selalu dilakukan di tempat praktik dengan pencahayaan yang ideal, tetapi juga dilakukan di fasilitas kesehatan yang berada di tempat terpencil yang minim peralatan dan pada kegiatan-kegiatan bakti sosial yang pencahayannya sangat tidak memadai. Untuk kasus seperti ini dapat ditambahkan pencahayaan dari senter kepala atau head lamp.
Dalam hal administrasi, dilakukan dengan mengikuti instruksi/panduan manual dari pabrik misalnya bola lampu sering dibersihkan agar debu atau kotoran yang menempel tidak mengurangi pencahayaan. Bola lampu yang mulai tidak berfungsi dengan baik segera diganti. ${ }^{1}$ Fluoresent tube pada lampu juga harus diganti setiap tahun karena pencahayaan akan berkurang seiring bertambahnya usia. ${ }^{17}$

\section{Radiasi ionisasi dan nonionisasi.}

Paparan radiasi ionisasi dan nonionisasi dapat terjadi dalam klinik gigi. ${ }^{21}$

\section{Radiasi ionisasi}

Radiasi ionisasi didefinisikan sebagai radiasi yang dapat mengionisasi molekul biologis. ${ }^{22}$ Dengan kemajuan dalam teknik diagnostik, pemanfaatan pemeriksaan radiologis telah meningkat banyak kali lipat dalam dua dekade terakhir. ${ }^{23}$ Paparan radiasi berbahaya bagi manusia. X-ray yang banyak digunakan dalam menunjang penentuan diagnosis di bidang medis dan kedokteran gigi merupakan jenis radiasi ionisasi. Literatur mengungkapkan bahwa paparan tunggal radiografi periapikal intraoral mampu menyebabkan efek genotoksik $^{22}$ dan menginduksi karsinogenesis pada sel yang terpapar. ${ }^{23}$

Efek biologi radiasi dikelompokkan ke dalam dua kategori yaitu efek deterministik dan efek stokastik. ${ }^{22,24}$ Efek deterministik didasarkan pada pembunuhan $\operatorname{sel}^{24}$ dan disebut juga efek nonstokastik. Efek deterministik tergantung pada waktu pemaparan, jenis, dan dosis radiasi. ${ }^{25}$ Dosis di bawah NAB tidak menimbulkan efek klinis, tetapi keparahan dari kerusakan sel akan meningkat seiring dengan semakin meningkatnya dosis radiasi. ${ }^{24}$ Efek stokastik adalah efek yang terjadi ketika seseorang menerima radiasi dosis tinggi. Efek ini mengalami peningkatan dengan bertambahnya dosis. ${ }^{25}$

Dosis radiografi intraoral $1-8 \mu \mathrm{Sv}$; panoramik $4-30 \mu \mathrm{Sv}$; sefalometrik $2-3 \mu \mathrm{Sv}$, prosedur CBCT $50 \mu \mathrm{Sv}$ atau lebih rendah untuk pemindaian berukuran kecil dan menengah, serta $100 \mu \mathrm{Sv}$ untuk pemindaian volume besar $(\mu \mathrm{Sv}=$ mikroSievert, $\mathrm{mSv}=$ 
miliSievert, $1 \mathrm{mSv}=1000 \mu \mathrm{Sv})^{26}$ Pengaturan NAB dosis radiasi pada masyarakat umum dan pekerja ditetapkan oleh Environmental Protection Agency (EPA), Nuclear Regulatory Commision (NRC), dan Department of Energy (DOE) untuk membatasi risiko kanker (Tabel 2). ${ }^{27}$

Tabel. 2 Ambang batas dosis radiasi tahunan $(\text { miliSievert } / \mathrm{mSv})^{27}$

\begin{tabular}{cc}
\hline $\begin{array}{c}\text { Ambang batas } \\
\text { dosis radiasi } \\
\text { tahunan }\end{array}$ & $\begin{array}{c}\text { Badan yang } \\
\text { menetapkan }\end{array}$ \\
\hline $\begin{array}{c}\text { Pekerja radiasi } \\
-50 \mathrm{mSv} \\
\text { Masyarakat umum } \\
-1 \mathrm{mSv}\end{array}$ & NRC \\
$\begin{array}{c}\text { Masyarakat umum } \text { member of the } \\
\text { public })\end{array}$ \\
$-0,25 \mathrm{mSv}$ & $\begin{array}{c}\text { (NRC, decommissioning } \\
\text { and decontamination all } \\
\text { pathways) }\end{array}$ \\
$\begin{array}{c}\text { Masyarakat umum } \\
-0,10 \mathrm{mSv}\end{array}$ & (EPA, air pathway) \\
Masyarakat umum & (EPA, drinking water \\
$-0,04 \mathrm{mSv}$ & pathway) \\
\hline
\end{tabular}

Dosis radiasi yang digunakan selama perawatan gigi mungkin tergolong rendah untuk pemeriksaan individu, tetapi pasien yang melakukan beberapa kali perawatan mendapatkan paparan radiografi gigi berulang. ${ }^{23}$ Oleh karena itu, prinsip-prinsip perlindungan dan keselamatan radiasi diperlukan untuk diikuti oleh dokter gigi. ${ }^{23}$

Upaya pengendalian bahaya radiasi ionisasi antara lain meliputi rekayasa engineering, administrasi, dan menggunakan APD. Rekayasa engineering dilakukan dengan mendesain tempat kerja yaitu memberikan jarak aman antara pekerja dengan sumber radiasi, ${ }^{28}$ dinding harus memiliki kepadatan atau ketebalan yang cukup, ${ }^{2}$ menggunakan sistem interlock, desain peralatan untuk meminimalkan penyebaran sinar, dan mengaktifkan tanda peringatan pada mesin ketika selesai melakukan prosedur radiologi. ${ }^{28}$

Dalam hal administrasi, dokter gigi wajib menerapkan kriteria seleksi saat meresepkan radiografi kepada pasien dan pemeriksaan radiografi harus dilakukan dengan langkah-langkah keamanan yang direkomendasikan. Para dokter gigi atau petugas radiologi harus menggunakan teknik pengambilan radiografi yang akurat sehingga dapat memberikan gambaran radiografi berkualitas baik yang dapat memaksimalkan hasil diagnostik dan menghindari paparan berulang terhadap radiasi. ${ }^{21}$ Selama paparan, operator harus meninggalkan ruangan atau mengambil posisi di belakang barrier atau dinding. Operator harus berdiri setidaknya 6 kaki dari pasien, pada sudut $90^{\circ}-135^{\circ}$ dari pusat sinar sinar-X. ${ }^{2}$ Mengganti peralatan dental $\mathrm{X}$-ray yang sudah lama $^{28}$ dan melakukan evaluasi berkala peralatan X-Ray untuk memastikan paparan radiasi yang tepat. Hal ini juga memberikan petunjuk jika ada kebocoran radiasi. Literatur mengungkapkan bahwa terdapat banyak dokter gigi yang tidak melakukan evaluasi berkala peralatan X-ray. Hal ini menyebabkan paparan radiasi yang tidak perlu akibat kebocoran radiasi. Dental X-ray perlu dikalibrasi dengan baik dan dilakukan setiap 3 tahun. $^{22}$

Penggunaan APD yang sesuai bagi pasien seperti apron, lead gloves, ${ }^{28}$ dan thyroid collar perlu diterapkan. ${ }^{22}$

\section{Radiasi nonionisasi}

Radiasi nonionisasi adalah serangkaian gelombang energi yang terdiri atas medan listrik dan magnet yang bergerak dengan kecepatan cahaya. $^{29}$ Radiasi nonionisasi meliputi microwave (MW), frekuensi radio (RF), spektrum ultraviolet (UV), ${ }^{25,29}$ visible light, inframerah (IR), dan extremely low frequency (ELF). ${ }^{29}$

Dalam kedokteran gigi, radiasi nonionisasi berasal dari alat light curing unit (LCU) dan laser. ${ }^{2}$ Radiasi nonionisasi dapat menimbulkan risiko kesehatan yang cukup besar bagi dokter gigi jika tidak dikontrol dengan baik. ${ }^{29}$ Pada awalnya LCU memancarkan sinar ultraviolet untuk photopolymerization bahan restorasi, kemudian beralih menggunakan blue light karena sinar UV memberikan efek samping terhadap kesehatan. Saat ini, terdapat tiga tipe LCU yang digunakan dalam kedokteran gigi yaitu halogen, plasma arc dan light 
emitting diode (LED). Sebagian besar LCU memancarkan blue light yang intens dalam panjang gelombang yang beragam, tetapi beberapa LCU juga menghasilkan UV (A) $(315-400 \mathrm{~nm}) .^{30}$

Penggunaan LCU dengan panjang gelombang yang lebih besar memberikan beberapa keuntungan bagi dokter gigi dan pasien yang mencakup waktu kerja lebih singkat, mengurangi kontaminasi saliva dan lebih sedikit ketidaknyamanan bagi pasien karena durasi pengerjaan lebih cepat. Meskipun demikian, pemakaian blue light dapat menyebabkan degenerasi retina. ${ }^{30}$

Istilah LASER merupakan akronim dari light amplification by the stimulated emission of radiation. Pada jaringan keras, laser digunakan untuk pencegahan karies, bleaching, restorative removal and curing, persiapan kavitas, hipersensitivitas dentin, modulasi pertumbuhan dan untuk tujuan diagnostik, sedangkan pada jaringan lunak digunakan dalam penyembuhan luka, menghilangkan jaringan hiperplastik yang menutupi gigi impaksi atau erupsi sebagian, terapi fotodinamik untuk keganasan, dan fotostimulasi lesi herpes. ${ }^{31}$

Laser yang digunakan dalam praktik kedokteran gigi dapat diklasifikasikan berdasarkan media aktif yaitu padat, cair, dan gas; berdasarkan aplikasinya terbagi menjadi laser untuk jaringan keras dan jaringan lunak; dan berdasarkan panjang gelombang yaitu Excimer 195-350nm, Alexandrite 337nm, Argon 455-515nm, He-Ne 637nm, Diode 655-980nm, Nd:YAG 1064nm, Ho:YAG 2100nm, Er, Cr:YSGG 2780nm, Er:YSGG 2790nm, Er:YAG 2940nm, CO2 10600nm. ${ }^{32}$ Laser umumnya memancarkan radiasi optik (UV, visible light, IR) dan dapat menyebabkan kerusakan pada mata dan kulit. ${ }^{29}$

Upaya pengendalian bahaya fisik radiasi nonionisasi yang dapat dilakukan meliputi rekayasa engineering, administrasi, dan menggunakan APD. Rekayasa engineering alat laser yaitu mengatur area kerja tidak mempunyai permukaan reflective dan memodifikasi ruangan menggunakan exhaust fan untuk ventilasi. ${ }^{28}$

Administrasi diterapkan dengan mela- kukan prosedur kerja yang aman termasuk menempatkan laser ke posisi stand by ketika tidak digunakan, aktivasi oleh satu operator, menyalakan laser dan LCU hanya ketika tip sudah diarahkan ke area kerja, dan mengikuti panduan manual penggunaan laser dan LCU. Tidak disarankan untuk menatap langsung ke sumber cahaya dan disarankan tetap menggunakan blue light filter. ${ }^{21,30}$ Dalam hal menggunakan APD, sebagian besar penelitian merekomendasikan penggunaan kacamata pelindung $^{21,28}$ sesuai dengan parameter penggunaan laser (panjang gelombang, watt, jenis atau tipe laser) untuk membatasi paparan pasien, operator dan asisten, ${ }^{21,30}$ serta menggunakan sarung tangan dan gown. ${ }^{28}$

\section{Percutaneous exposure incident (PEI)}

Percutaneous exposure incident (PEI) adalah istilah yang mencakup cedera akibat tertusuk jarum suntik bekas pakai dan benda tajam. ${ }^{2,21,33}$ Penelitian yang dilakukan oleh Shah ${ }^{34}$ tahun 2006 di Washington melaporkan sebanyak $87 \%$ profesi dokter gigi mengalami insiden tertusuk jarum suntik. $^{34}$ Selain itu, cedera yang dapat dialami oleh dokter gigi dan pernah dilaporkan ialah terkena proyektil bor gigi akibat bor gigi yang tidak terpasang dengan benar pada head hand piece (Gambar 3). ${ }^{35}$

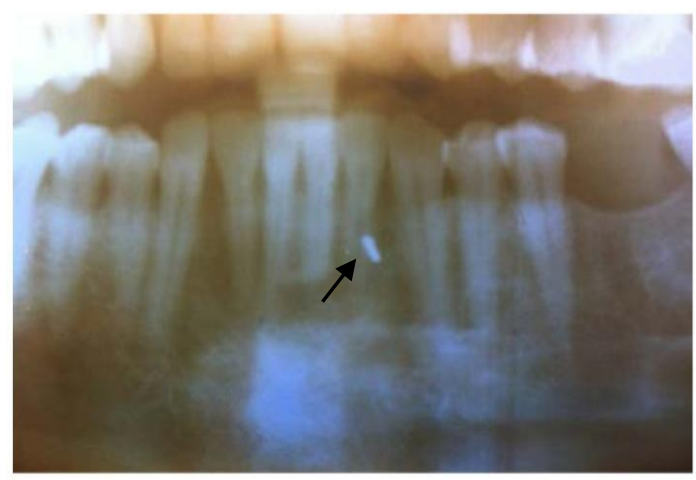

Gambar 3. Gambaran radiografi panoramik dari dokter gigi yang terkena proyektil bor gigi pada saat melakukan perawatan. Sumber: Hailu et al, 2017.35

Selain menyebabkan bahaya fisik, PEI juga termasuk bahaya biologi karena dapat menularkan infeksi. ${ }^{2,21,33}$ Oleh karena itu perlu dilakukan upaya pengendalian untuk 
meminimalkan potensi bahaya yang meliputi administrasi dan memakai APD. Administrasi diterapkan dengan mengikuti SOP jarum bekas sekali pakai dengan teknik one hand. ${ }^{34}$ Praktisi gigi juga harus mengikuti pedoman dan instruksi keselamatan pabrik dari hand piece. Pedoman penggantian untuk setiap instrumen merupakan salah satu instruksi paling penting yang perlu diikuti untuk menghindari kecelakaan atau cedera pada pasien atau staf selama prosedur gigi apapun. ${ }^{35}$ Penggunaan APD meliputi sarung tangan, pelindung wajah/face shield, dan pelindung mata atau goggle. ${ }^{21}$

\section{Suhu ekstrim}

Melakukan perawatan gigi pada masa pandemi Covid-19 menuntut dokter gigi melakukan upaya perlindungan diri maksimal. Alat pelindung diri yang direkomendasikan untuk dokter gigi yaitu perlindungan level III berupa masker N95 atau ekuivalen, gown allcover, pelindung mata/ goggle, pelindung wajah/face shield, sarung tangan karet steril sekali pakai, headcap, dan apron (Gambar 4). ${ }^{36,37}$

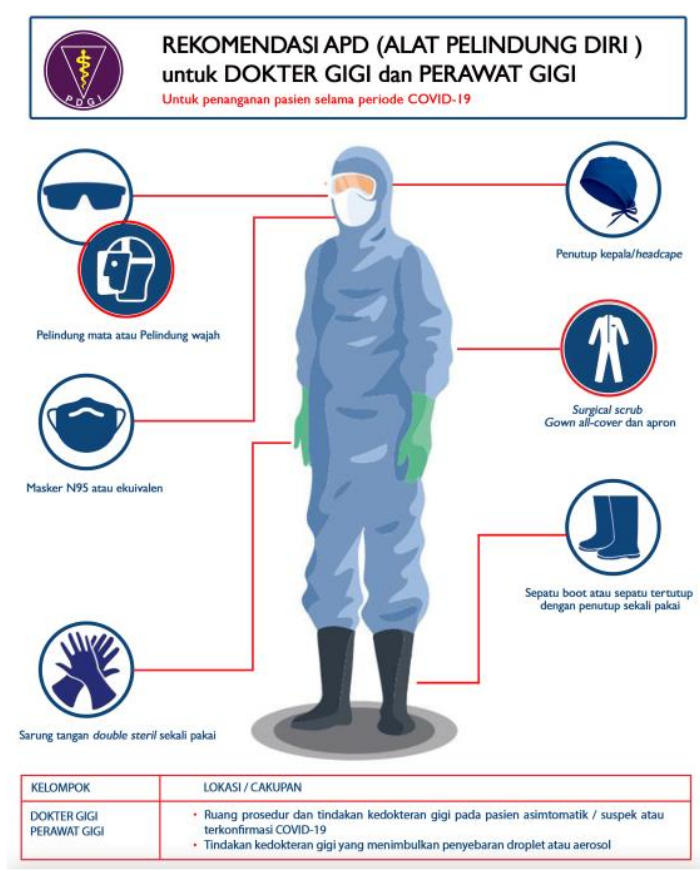

Gambar 4. Rekomendasi APD untuk dokter gigi dan perawat gigi untuk penanganan pasien. Sumber: Satgas PB-PDGI, 2020. ${ }^{36}$
Hal ini sangat penting untuk melindungi dokter gigi dari virus, tetapi di lain sisi dapat menyebabkan heat stress dan kelelahan sehingga dapat mengurangi daya tahan serta kinerja fisik seseorang. Peningkatan suhu tubuh juga dapat mengurangi kinerja kognitif. ${ }^{38,39}$

Upaya pengendalian terhadap bahaya fisik berupa suhu ekstrim di antaranya ialah rekayasa engineering dan administrasi. Rekayasa engineering yaitu menambahkan mesin pendingin berupa air conditioner (AC), serta mengatur sirkulasi dan kelembaban udara. ${ }^{36}$ Administrasi diterapkan dengan membagi jadwal kerja dan istirahat untuk meminimalkan kenaikan panas tubuh yang berlebihan, makan secara teratur dan memastikan tubuh terhidrasi, mempertahankan keseimbangan elektrolit saat berkeringat banyak atau untuk periode yang lama, serta menghindari konsumsi alkohol. Dokter gigi juga perlu mengenali tandatanda stres akibat panas dan jangan menunggu untuk merasa tidak enak sebelum beristirahat, meminimalkan peralatan yang dibawa, serta efisien dalam gerakan. ${ }^{36}$

\section{Simpulan}

Pengendalian bahaya fisik berdasarkan hierarki pengendalian bahaya pada pekerjaan dokter gigi dapat dilakukan dengan cara substitusi, rekayasa engineering, administrasi, dan menggunakan alat pelindung diri (APD).

\section{Ucapan terima kasih}

Penghargaaan yang setinggi-tingginya disampaikan kepada drg. Dinar A. Wicaksono, Sp.KG, M.Kes dan drg. Aurelia S.R. Supit, M.Kes atas bantuan yang diberikan dalam penulisan artikel ini.

\section{Konflik Kepentingan}

Penulis menyatakan tidak terdapat konflik kepentingan dalam studi ini.

\section{DAFTAR PUSTAKA}

1. Menteri Kesehatan RI. Peraturan Menteri Kesehatan Republik Indonesia Nomor 56 Tahun 2016 tentang penyelenggaraan pelayanan penyakit akibat kerja. 
Jakarta: 2016; p. 10.

2. Reddy KS, Majumder DSP, Doshi D, Kulkarni S, Reddy BS, Reddy MP. Occupational hazards in dentistry. J Res Adv Dent. 2017;6(2):110-22.

3. Baig NN, Aleem SA. Occupational hazards among dental surgeons in Karachi. J Coll Physicians Surg Pak. 2016;26(4): 320-2.

4. Vodanović M, Sović S, Galić I. Occupational health problems among dentists in Croatia. Acta Stomatol Croat. 2016; 50(4):310-20

5. Al-Rawi NH, Al Nuaimi AS, Sadiqi A, Azaiah E, Ezzeddine D, Ghunaim Q, Abbas Z. Occupational noise-induced hearing loss among dental professionals. Quintessence Int. 2019;50(3):245-50

6. Peraturan Menteri Kesehatan Republik Indonesia Nomor 52 Tahun 2018 tentang keselamatan dan kesehatan kerja di fasilitas pelayanan kesehatan. 2018; p. 31-2.

7. British Standard Institution. ISO 45001: 2018 Occupational Health and Safety management systems. Geneva Swiss, 2018.

8. Djatmiko RD. Keselamatan dan Kesehatan Kerja. Yogyakarta: Deepublish, 2016; p. 15-6.

9. The National Institute for Occupational Safety and Health /NIOSH. The hazard control hierarchy [homepage on the internet]. 2015 [cited 2020 Apr]. Available from:https://www.cdc.gov/niosh/topics/ hierarchy/default.html.

10. Yuliani HR. E-learning Keselamatan dan Kesehatan Kerja (K3). Yogyakarta: Deepublish, 2014; p. 28-9.

11. Qsaibati ML, Ibrahim O. Noise levels of dental equipment used in dental college of Damascus University. Dent Res J . 2014;11(6):624-30.

12. Elmehdi HM. Noise Levels in UAE Dental Clinics: Health impact on dental healthcare professionals. Journal of Public Health Frontier. 2013;2(40): 189-92.

13. Peraturan Menteri Kesehatan Republik Indonesia. Peraturan Menteri Kesehatan Republik Indonesia Nomor 48 tahun 2016 tentang standar keselamatan dan kesehatan kerja perkantoran. Jakarta, 2016

14. Sampaio, Fernandes JC, Carvalho AP, Gallas M, Vaz P, Matos PA. Noise levels in dental schools. Eur J Dent Educ. 2006;
10:32-7.

15. Kadanakuppe S, Bhat PK, Jyothi C, Ramegowda C. Assessment of noise levels of the equipments used in the dental teaching institution, Bangalore. Indian J Dent Res. 2011;22(3):424-31.

16. Messano GA, Petti S. General dental practitioners and hearing impairment. J Dent. 2012;40(10):821-8.

17. Eclipse Dental Engineering Ltd. Top Tips for Dental Surgery Lighting. [homepage on the internet]. c2020 [updated 2020 July; cited 2020 July 2]. Available from: https://eclipse-dental.com/dental-blogarticles/top-tips-for-dental-surgerylighting/\#: :text=The\%20right\%20dent al\%20lighting\%20should,light $\% 20$ can $\% 20$ affect\%20how\%20tired

18. Alvin GW, Meyer A, Wu W, Wichman CS. Lighting conditions used during visual shade matching in private dental offices. J Prosthet Dent. 2016; 115(4): 496

19. Stamatacos C, Harrison JL. The possible ocular hazards of LED dental illumination applications. J Tenn Dent Assoc. 2013;93(2):25-9.

20. Surgiden. High speed handpiece with fiber optic light source [image on the internet]. 2020. [cited 2020 July 2]. Available from: http://www.surgiden. com/products/fiberoptic.php

21. Leggat PA, Kedjarune E, Smith DR. Occupational health problems in modern dentistry: a review. Industrial Health. 2007; 45:611-21.

22. Singh G, Sood A, Kaur A, Gupta D. Pathogenesis, clinical features, diagnosis, and management of radiation hazards in dentistry. Open Dent J. 2018;12:74252.

23. Chaudhry M, Jayaprakash K, Shivalingesh K, Agarwal V, Gupta B, Anand R, et al. Oral radiology safety standards adopted by the general dentists practicing in National Capital Region (NCR). J Clin Diagn Res. 2016;10(1):42-5.

24. Okano T. Radiation dose and protection in dentistry. Jpn Dent Sci Rev. 2010; 46(2):112-21.

25. Choudhary S. Deterministic and stochastic effects of radiation. Canc Therapy \& Oncol Int J. 2018;12(2): CTOIJ.MS. ID. 555834

26. International Atomic Energy Agency Vienna 
International Centre. Radiation doses in dental radiology [homepage on the internet]. Austria; 2020 [cited 2020 July 4]. Available from: https://www.iaea. org/resources/rpop/healthprofessionals/dentistry/radiation-doses

27. Health Physics Society. Regulatory Dose Limits [homepage on the internet]. 2016 [cited 2020 July 4]. Available from: https://hps.org/publicinformation/ ate/faqs/regdoselimits.html

28. Soaita C. Identifying occupational risks in dentistry. Procedia Technology. 2014; 12:558-65.

29. Occupational Safety and Health Administration/OSHA.Non-Ionizing Radiation [homepage on the internet]. Washington; 2020 [cited 2020 July 4]. Available from: https://www.osha.gov/ SLTC/radiation_nonionizing/

30. Alasiri A, Algam HA, Alasiri RA. Ocular hazards of curing light units used in dental practise-a systematic review. The Saudi Dental Journal. 2019;31(2): 173-80.

31. Verma SK, Mahesdewi S, Singh RK, Chaudhari PK. Laser in dentistry; an innovative tool in modern dental practise. Natl J Maxillofac Surg. 2012; 3(2):124-32

32. Pendyala C, Tiwari RVC, Dixit H, Augustine V, Baruah Q, Baruah K. LASERS and its applications in dentistry. International Journal of Oral Health and Medical Research (IJOHMR). 2017; 4(2):49.
33. Sawitri MR, Mulyono. Analisis risiko pada pekerjaan dokter gigi di Kabupaten dan Kota Probolinggo. The Indonesian Journal of Occupational Safety and Health. 2019;8(1):29-37.

34. Shah SM. Merchant AT, Dosman JA. Percutaneous injuries dental professsionals in Washington State. BMC Public Health. 2006;10(6):269.

35. Hailu K, Lawoyin D, Glascoe A, Jackson A. Unexpected hazards with dental high speed drill. Dent. J (Basel). 2017;5(1): 10 doi:10.3390/dj5010010

36. Satgas PB-PDGI. Rekomendasi APD (Alat Pelindung Diri) untuk dokter gigi dan perawat gigi untuk penanganan pasien selama periode Covid-19. 2020.

37. Gugus Tugas Percepatan Penanganan Covid19. Rekomendasi standar penggunaan APD untuk penanganan Covid-19 di Indonesia. 2020 Maret.

38. Global heat health information network. Q\&A: How can health workers and other responders manage heat stress while wearing personal protective equipment (PPE)? Limits [homepage on the internet]. 2020 [cited 2020 July 5]. Available from: http://www.ghhin. org/heat-and-covid-19/PPE

39. Royal College of nursing. Personal protective equipment (PPE) and Covid-19. [homepage on the internet]. 2020 [cited 2020 July 5]. Available from: https://www. rcn.org.uk/get-help/rcn-advice/ personal-protective-equipment-ppeand-covid-19. 